$$
\begin{array}{ll} 
& F \\
N & 845 \\
0 & .3 \\
5 & R_{31} \\
0 & \\
3 &
\end{array}
$$




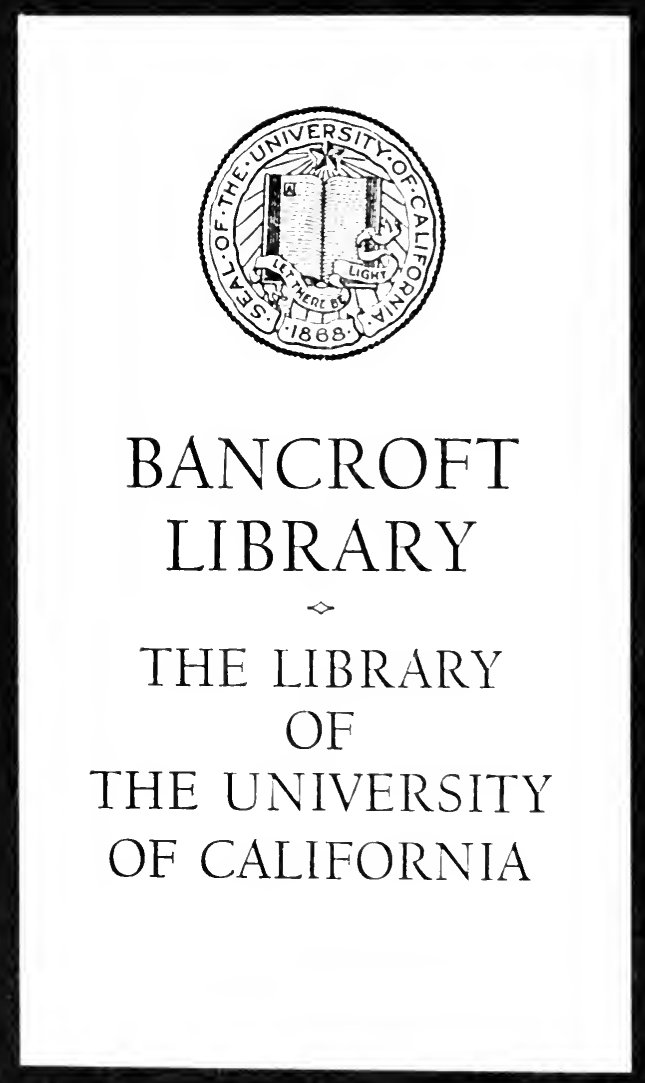



Digitized by the Internet Archive in 2007 with funding from Microsoft Corporation 
Reprinted from Economic Geology, Vol. II, No. 7, October-November, 1907.

THE ASSOCIATION OF ALUNITE WITH GOLD IN THE GOLDFIELD DISTRICT, NEVADA

FREDERICK LESLIE RANSOME 


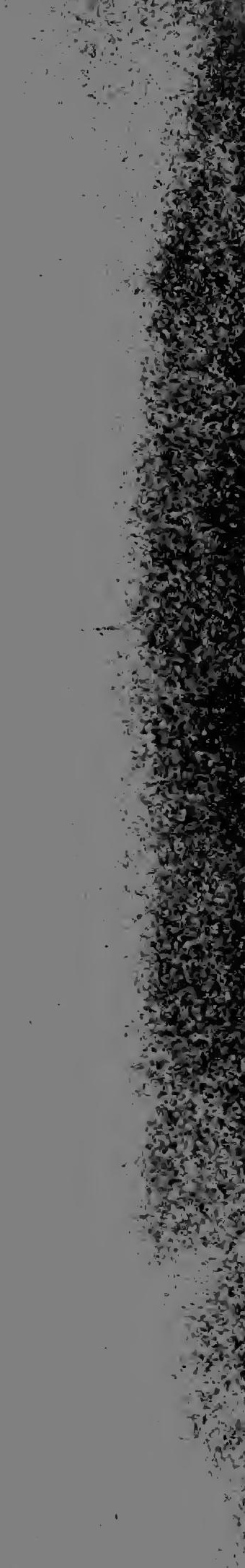




\title{
THE ASSOCIATION OF ALUNITE WITH GOLD IN THE GOLDFIELD DISTRICT, NEVADA. ${ }^{1}$
}

\author{
Frederick Leslie Ransome.
}

\section{INTRODUCTION.}

Alunite, a hydrous sulphate of potassium and aluminium with the formula $\mathrm{K}_{2} \mathrm{O} \cdot 3 \mathrm{Al}_{2} \mathrm{O}_{3} \cdot 4 \mathrm{SO}_{3} \cdot 6 \mathrm{H}_{2} \mathrm{O}$, is one of those minerals the apparent rarity of which is probably due in no small measure to inconspicuousness. The material was first noted at Tolfa, near Rome, where it was used as early as the fifteenth century for the manufacture of potassium alum $\left(\mathrm{K}_{2} \mathrm{O} \cdot \mathrm{Al}_{2} \mathrm{O}_{3} \cdot 4 \mathrm{SO}_{3} \cdot 24 \mathrm{H}_{2} \mathrm{O}\right){ }^{2}$ This salt, containing 2 parts less of $\mathrm{Al}_{2} \mathrm{O}_{3}$ with $\mathrm{I} 8$ parts more of water, is obtained from the alunite by roasting and lixiviation. Alunite is found also on some of islands of the Grecian Archipelago, near Muszay in Hungary, on Mount Dore in France and in a few other localities in Europe, as well as with the opal of Queretaro, in Mexico. In the United States it has been described in the Rosita Hills, ${ }^{3}$ on Calico Peak near Rico, ${ }^{4}$ in the National Belle Mine near Silverton, ${ }^{5}$ and at Cripple Creek, ${ }^{6}$ all in Colo-

${ }^{2}$ Published with the permission of the Director of the U. S. Geological Survey.

${ }^{2}$ For the latest account of this celebrated locality, with a bibliography, see L. De Launay, "La Métallogénie de l'Italie." Tenth Geological Congress, Mexico, 1906, pp. 125-132.

'Cross, Whitman, "Geology of Silver Cliff and the Rosita Hills, Colorado." 17th Ann. Rept. U. S. Geol. Survey, Pt. 2, 1896, pp. 52-56. Also Am. Jour. Sci., 3d ser., vol. 4I, I89I, pp. 466-475.

"Cross and Spencer. "The Geology of the Rico Mountains, Colorado." 21st Ann. Rept. U. S. Geol. Survey, Pt. 2, 1900, pp. 92-94.

"Hurlbut, E. B. " On Alunite from Red Mountain, Ouray County, Colo." Am. Jour. Sci., 3d ser., vol. 48, I894, pp. I30-13r. Also Ransome, F. L. "A Report on the economic geology of the Silverton Quadrangle, Colorado." Bull. U. S. Geol. Survey No. I82, I901, p. 235.

-Lindgren and Ransome. "Geology and Gold Deposits of the Cripple Creek District, Colorado.” Profess. Paper U. S. Geol. Survey No. 54, 1906, p. 125 . 
rado. It occurs also at Tres Cerritos, Mariposa County, California. $^{1}$

Mr. IV. Lindgren ${ }^{2}$ found alunite in the Ryerson mine near Morenci, Arizona, associated with pyrite and kaolin. He regarded it (page 193) as formed by the attack of descending sulphuric acid solutions upon sericite away from free oxygen.

Until recently geologists have regarded alunite as formed exclusively by the attack of sulphurous fumarolic vapors upon feldspatchic rocks. ${ }^{3}$ At Cripple Creek, however, the mineral was found only in the oxidized ore, and, like the kaolinite of that district, is probably secondary with reference to the original telluride ores. De Launay, ${ }^{4}$ moreover, has recently maintained with cogency that the alunite of Tolfa is probably not, as formerly supposed, a solfataric product, but is due to the action of percolating surface water, charged with sulphuric acid by the oxidation of pyrite, upon a particularly feldspathic facies of the trachyte. It is accordingly no longer justifiable to regard the occurrence of alunite as proof of former fumarolic activity. The mineral may form under very different sets of conditions and it is necessary, in seeking the explanation of any occurrence of it, to keep alternative hypotheses in mind.

In all four of the Colorado localities the alunite occurs in regions which contain ore deposits. In the Rosita Hills and in the Rico and Silverton districts it is apparently not a product of superficial oxidation. No close kinship between this mineral and the ores, however, has been shown, although it was doubtless recognized by all the workers in those districts that there might be some genetic relation between the metallic sulphides and the volcanism of which the sporadic solfataric metamorphism of feldspathic rocks to quartz-alunite aggregates was one manifestation. It is worth noting in this connection that the indexes of

'Turner, H. W. "Rocks and Minerals from California." Am. Jour. Sci, $4^{\text {th }}$ ser., vol. 5, I898, pp. 424-426.

2 "The Copper Deposits of the Clifton-Morenci District, Arizona." Profess. Paper U. S. Geol. Survey No. 43, 1905, pp. I19-120, 169 and 193-194.

"Iddings, J. P. " Rock Minerals." New York, 1906, p. 476.

'Op. cit. 
two of the best and most recent works ${ }^{1}$ on ore deposits contain no reference to alunite, showing that the mineral has not been commonly recognized as one intimately associated with ores. Neither is it mentioned, so far as I am aware, in President C. R. Van Hise's work on metamorphism. ${ }^{1}$ Professor J. H. L. Vogt, ${ }^{2}$ however, in discussing metasomatic vein-processes, has remarked: "I would mention also the formation of alum-stone; quartzalunite rocks; quartz-diaspore rocks, etc. ; and also the formation of bauxites, etc. But I do not know that these changes have been anywhere observed in genetic relation with ore-veins."

In the Goldfield district alunite is so abundant and so generally associated with the intense alteration accompanying ore deposition that it must be looked upon as one of the most characteristic minerals of the gold deposits. This close association of the gold with a mineral which apparently had not been recognized in Nevada prior to the present investigation and which has been reported in comparatively few localities elsewhere, seems worthy of some description, especially as the relation promises to throw light upon the origin of the ores.

\section{ROCKS OF THE DISTRICT.}

For a preliminary account of the geology of Goldfield the reader is referred to an earlier publication. ${ }^{3}$ A full description of the geology and ore deposits is in preparation and will appear as one of the professional papers of the U. S. Geological Survey. It is sufficient in this place to state that the ores occur in middle or early Tertiary rhyolite, latite, andesite and dacite. Nearly all of these are extrusive flows, but the dacite, which contains most of the important mines, is an intrusive sheet, although the intrusion probably took place beneath a cover of volcanic rocks which

\footnotetext{
${ }^{1}$ Beck, Richard. "Lehre von den Erzlagerstätten." Berlin, I90r. StelznerBergeat. " Die Erzlagerstätten.” Leipzig, 1904-1906.

1 "A Treatise on Metamorphism." Monog. U. S. Geol. Survey No. 47, 1904.

2 "Problems in the Geology of Ore Deposits." Trans Amer. Inst. Mining Engineers, vol. 31, 1902, p. 150.

'Ransome, F. L. "Preliminary Account of Goldfield, Bullfrog, and Other Mining Districts in Southern Nevada." Bull. U. S. Geol. Survey No. 303, 1907.
} 
was not of great thickness. The ore-bearing rocks rest upon, or cut through, a pre-Tertiary foundation of granitic rock with which is involved some Cambrian shale, and are themselves, in outlying parts of the district, unconformably overlain by tuffaceous lake sediments and later Tertiary lavas.

Although comparatively unaltered representatives of most of the rocks named may be found within the district, yet the metamorphism which they have undergone over much of the area is of a most conspicuous kind. Dark pyroxene-andesites, dacite, and rhyolite have alike been changed to nearly white aggregates of secondary minerals. Such products, as a rule, retain only traces of the original textures of the igneous rocks from which they have been derived. To detect and interpret these traces requires patient field observation of the progressive stages of alteration, supplemented by microscopical study.

\section{TYPES OF ALTERATION.}

Three types or stages of alteration are recognizable. Where the chemical activity has been most intense the rocks have been changed to porous, fine-grained aggregates consisting essentially of quartz. This is the material of which are composed the hundreds of craggy points and ledges which are one of the most characteristic features of the topography of the district. Although most of these ledges, so far as known, contain no ore bodies, yet, until recently, no ore has been found that was not in or alongside such quartz rock. Some of the discoveries made in 1906, however, show that very rich bodies of ore may occur at places where there is no siliceous outcrop.

The second type of alteration is one in which the rock is changed to a comparatively soft, light-colored mass of quartz, kaolinite, alunite and pyrite. At any given locality the boundary between the rocks representing the two kinds of alteration may be fairly sharp; but the proportions of quartz, kaolinite and alunite vary widely, and consequently, over the field at large, gradations in composition and hardness may be found between these two typical metamorphic products. Both types are usually 
associated with the ores and are most conspicuously displayed over a belt of country stretching east from Goldfield past Preble Mountain. This mountain, in fact, is composed chiefly of andesite and dacite which have undergone alteration of the kinds described.

The third type of alteration has effected less conspicuous results than the other two and its products are not closely associated with the ores. It consists in the development of calcite, quartz, chlorite, epidote and pyrite at the expense of the original minerals and groundmass and is thus propylitic in character. It is rather sharply marked off from the second type by the presence of calcite and the absence of alunite, these minerals not having yet been observed together in the same specimen. ${ }^{1}$ Rocks which have undergone this form of alteration, chiefly andesite, latite and dacite, still retain something of their original color and texture, the principal external sign of change being a greenish tint instead of the usual dark gray of the fresh rock, and a lack of luster in the phenocrysts.

\section{GENERAL OCCURRENCE OF THE ALUNITE.}

Attention was first directed to the occurrence of alunite in the district by the finding of small nests, or crystalline aggregates, up to five millimeters in diameter, of a pale pink mineral in a greatly altered nearly white rock exposed on the east shoulder of Vindicator Mountain, about two miles northeast of the town of Goldfield. The rock contains quartz phenocrysts and was probably originally a rhyolite. The microscope shows that the

${ }^{1}$ Since this was written, very finely crystalline calcite, sericite and probably some kaolinite have been found associated with much larger crystals of alunite in an altered rhyolite from the east slope of Vindicator Mountain. The molecular ratio of soda to potash in the alunite, as determined by Dr. Hillebrand, is as 40 to 45 . It is possible, however, that the result obtained for potash may be high in consequence of some decomposition of the sericite by the sulphuric acid used to dissolve the alunite.

The occurrence together of alunite and calcite, apparently developed simultaneously, shows that the alteration took place under conditions which did not permit the free escape of carbon dioxide. It is scarcely conceivable, for example, that calcite could form in the presence of sulphuric acid percolating down from an overlying deposit of oxidizing pyrite. 


\section{EXPLANATION OF PLATE IX.}

FIG. I. Photomicrograph of thin section of altered dacite (G. 398) from $D$ level of the Combination Mine, Goldfield. Magnified to diameters. Nicols crossed.

The section shows a characteristic pseudomorphous aggregate of alunite $(A)$, and quartz $(Q)$ after a labradorite phenocryst. In this case there is an isotropic material $(O)$ present which is probably opal. The groundmass is a fine-grained aggregate of quartz, alunite and pyrite, the crystals of the last mineral (black) being in some places grouped in pseudomorphous aggregates after hornblende and biotite.

FiG. 2. Photomicrograph of thin section of altered dacite (G. 634) from the 200-foot level of the Florence Mine, Goldfield. Magnified 40 diameters. Ordinary light.

The section shows rather more alteration than the preceding, little of the original texture of the dacite remaining. Pyrite (black) is abundant and is crystallized with alunite $(A)$. The latter mineral exhibits characteristic lath-shaped sections with irregular ends and felty aggregation. It has evidently devcloped in some places along devious cracks. There is much quartz $(Q)$ in the rock but it is for the most part too finely crystalline to appear clearly in the photograph. 


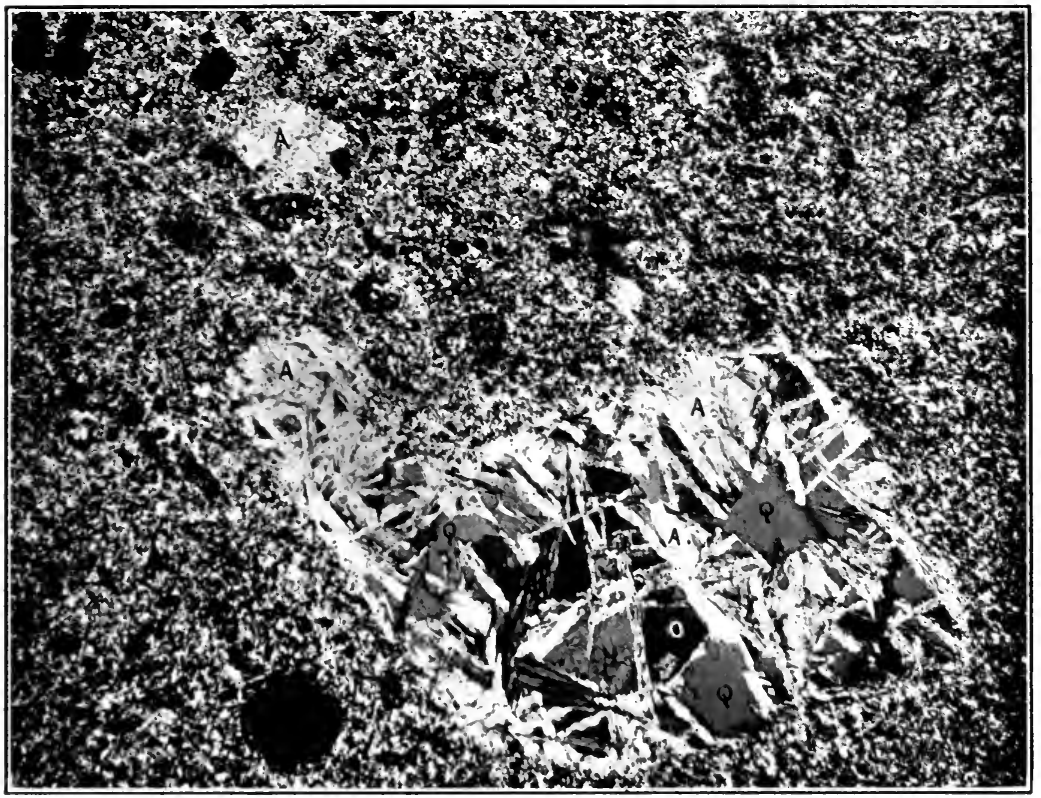

FIG 1

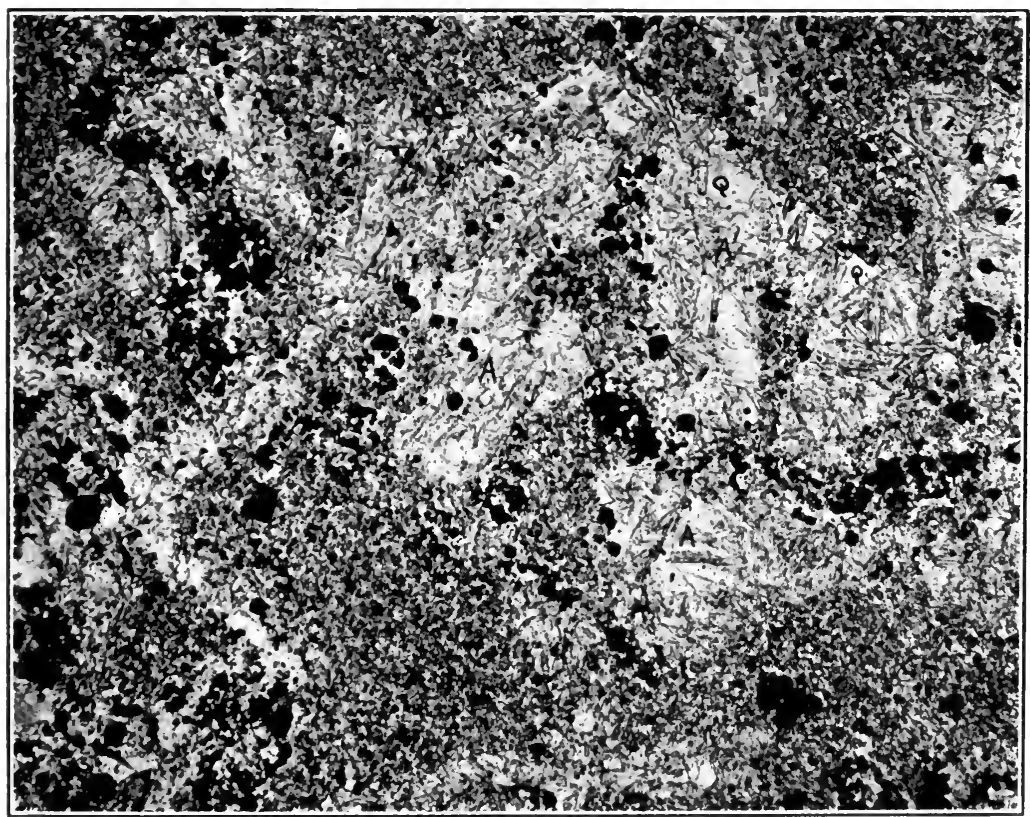

FIG. 2. 

feldspar phenocrysts, as well as the groundmass, have been altered to an aggregate of quartz and alunite, the optical determination of the latter mineral being checked by independent chemical tests in the Survey laboratory by Dr. W. F. Hillebrand and Dr. W. T. Schaller. With the alunite is associated a subordinate quantity of an anhedral, ${ }^{1}$ colorless mineral of high refractive index, strong birefringence and possessing a single wellmarked cleavage. The mineral is biaxial and optically negative, the plane of the optic axes coinciding with the cleavage. It resembles diaspore but differs from that mineral in being optically negative. It has not yet been identified. Undoubted diaspore has been found intergrown with alunite, in the altered dacite of the Florence mine.

Microscopic study of the bleached, altered rocks of the district has revealed alunite in nearly all of them. The rhyolite forming the summit of Columbia Mountain, just north of the towns of Goldfield and Columbia, has been changed to a quartz-alunite rock, the alunite, with some quartz, forming pseudomorphs after the feldspar phenocrysts which probably 'were originally orthoclase. Alunite is very abundant in the altered andesite and dacite of Preble Mountain and vicinity and is present in practically all of the altered dacite which forms the country rock of the Combination, Florence, January, Red Top, Jumbo and other mines near Goldfield. It also occurs in abundance directly associated with the sulphide ores in these mines, in some places, particularly in the January mine, as a soft, easily pulverized material, of snow white or faint pink color, which is not always distinguishable on mere inspection from certain pure forms of kaolinite which occur in the mines of this and other districts. At Goldfield, the delicate pink tint of the alunite is rather characteristic and serves often as a rough-and-ready means of distinguishing it from the kaolinite with which it is often associated. Close inspection of the altered rocks in which alunite is abundant usually reveals

\footnotetext{
${ }^{1}$ Anhedral $=$ without crystal faces, xenomorphic, allotriomorphic. See Cross, Iddings, Pirsson and Washington, "The Texture of Igneous Rocks," Journal of Geology, vol. 14, 1906, p. 698.
} 
this faint pink color in the aggregates which have replaced the original feldspar.

As a constituent of altered rocks in the Goldfield district, the alunite does not have complete crystal form. It is tabular in habit, the basal pinacoid being well developed and the rhombohedral faces being absent. In thin sections it shows distinct cleavage parallel to the basal planes and parallel extinction with reference to the cleavage. The birefringence is apparently rather stronger than the difference $\gamma-a=0.018$ given in the table of Lévy and Lacroix. ${ }^{1}$ the interference colors in good thin sections being mostly yellow but rising in places to red or blue of the first order. The mineral gives a positive uni-axial interference figure, in sections showing no cleavage. The index of refraction is distinctly higher than the balsam of the slide (1.54), that given for the alunite of Tolfa being $\omega=1.572$ and $\epsilon=1.592 .^{2}$ The most decisive optical means of distinguishing the mineral from the optically negative sericite which it resembles in habit and refraction, is by means of the quartz wedge or gypsum plate. Sericite shows the higher interference colors when the section is turned with the cleavage at right angles to the direction of greatest elasticity $(X)$ of the plate or wedge, while alunite shows the brighter colors when the basal cleavage is parallel to this direction.

The soft massive alunite, such as occurs in the January mine, when gently crushed on a microscopical slide and stirred in a drop of water, shows under a high power of the microscope thin, colorless scales of hexagonal outline. The average diameter of those examined is less than 0.05 millimeter, and such is their tenuity that no crystal faces can be recognized on the edges of the basal-pinacoidal scales.

\section{COMPARISON OF FRESH AND ALTERED DACITE.}

Inasmuch as the largest and richest ore bodies are in the dacite and as the rock is uniform in character, it was chosen for a close

\footnotetext{
" "Les Minéraux des Roches." Paris, 1888. Also Iddings, J. P. “Rocl Minerals." New York and London, 1906.

' Iddings, J. P. Op. cit., p. 476.
} 
study of the alteration effected by the ore-depositing agencies. Such comparison is especially favored by the fact that the most intense alteration is often local and consequently it is possible to obtain specimens of fresh and altered rock within moderate distances of each other. The two specimens of dacite analyzed and compared were taken about one and one fourth miles apart.

The unaltered and typical dacite is a dark gray rock with abundant phenocrysts of plagioclase, up to a centimeter in length, lying in a dark aphanitic groundmass. There are present, also, less numerous phenocrysts of augite and biotite with occasional anhedral grains of quartz. The volumetric ratio of phenocrysts to groundmass is estimated at rather less than $\mathrm{I}$ to 3 .

Under the microscope the feldspar phenocrysts prove to be labradorite of the approximate composition $\mathrm{Ab}_{1} \mathrm{An}_{1}$. They are perfectly fresh, with slightly rounded euhedral ${ }^{1}$ outlines. A noticeable feature is the presence in many crystals of closely crowded minute inclusions of glass which in some cases constitute cloudy cores or kernels, in others sharply bounded shells, the center of the crystal being clear. The augite crystals are roughly euhedral or subhedral, with a maximum measured extinction angle, $Z \wedge C$, of about $45^{\circ}$. The biotite occurs in the usual short, rather irregular pseudo-hexagonal prisms. Both biotite and augite are entirely fresh. The quartz phenocrysts are anhedral, with rounded, embayed or sharply angular outlines.

Hornblende is very abundant but is confined almost exclusively to the groundmass, most of the crystals being comparable in size rather with the feldspar microlites than with the phenocrysts just described. The largest hornblende crystal in the thin section studied is about half a millimeter in length. It should be said, however, that in dacite from other parts of the district the hornblende occurs as phenocrysts.

The feldspar microlites in the groundmass are at least in part labradorite of as calcic composition as the phenocrysts. They, the hornblende, and a little magnetite and apatite, are imbedded in an abundant glass, which in transmitted light is gray, with

${ }^{1}$ Euhedral $=$ bounded by crystal faces; idiomorphic, automorphic. 
incipient crystals, or crystallites. One crystal of titanite, 0.3 millimeter in length, is in the thin section studied.

A chemical analysis of this rock, made by Mr. George Steiger in the Survey laboratory, is given under I. in the table on page 680.

The arbitrary norm of this rock, calculated from analysis in accordance with the plan of the "quantitative classification," is as follows:

NorM OF DAcite.

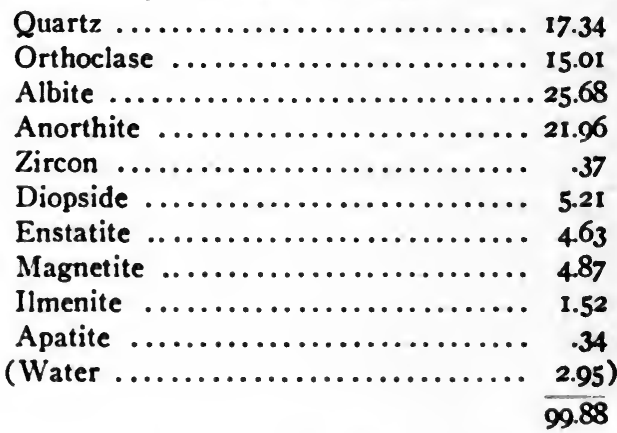

As the rock contains much undifferentiated glass no close calculation of its real mineralogical composition, or mode, is possible. The norm and chemical analysis show that the rock is a tonalose in the terminology of the quantitative classification.

The altered dacite, of which a chemical analysis by Mr. George Steiger is given under II., was taken from the D level of the Combination Mine, about 235 feet below the surface and in a part of the mine where no apparent oxidation had taken place. The original water level in this mine appears to have been at about I 30 feet from the surface, near which depth the oxidized ore gives place to sulphides. The rock analyzed is the typical wall-rock of this and adjacent mines.

${ }^{2}$ Cross, Iddings, Pirsson and Washington. "The Quantitative Classification of Igneous Rocks." Chicago and London, I903.

For the benefit of the reader who may not have had occasion to familiarize himself with modern petrology it may be explained that the "norm" is a classificatory expedient and is usually very different from the actual mineral composition, or "mode." The dacite for instance really contains no orthoclase, the potassium being combined in biotite and in the glass of the groundmass. 
The altered rock is light-gray, flecked with numerous dull white spots which represent the original feldspar phenocrysts. The few quartz phenocrysts are unchanged, but the ferromagnesian, or, more briefly, femic, minerals have wholly disappeared. Pyrite, in small, disseminated crystals, is abundant.

Under the microscope, it is seen that the only original constituents are the quartz phenocrysts, even these showing some development of pyrite along irregular microscopic cracks, and an occasional small crystal of zircon. The feldspars are changed to aggregates of minutely crystalline kaolinite and tabular crystals of alunite, the latter being sometimes arranged in sheaf-like bunches. (See Plate IX.) The alunite has the form characteristic of its occurrence. in this district, sections cut at large angles with the basal pinacoid having the shape of narrow laths with irregular ends. The length of these lath-shaped sections rarely exceeds half a millimeter. The alunite, when cursorily examined under a low-power lens, may easily be mistaken for sericite (muscovite), although of course this error is quickly dispelled on closer study, sericite being optically negative and alunite positive. The interference colors, moreover, although bright, particularly in the larger crystals, are of a lower order than those of sericite. Quartz also accompanies the alunite and kaolinite in some of the pseudomorphs after labradorite. (See Plate IX., Fig. I.)

The former femic constituents can be recognized from the fact that they contain little or no kaolinite, the quartz and alunite being here associated with abundant pyrite. In some cases the pseudomorphous aggregate still preserves a suggestion of the former cleavage of the biotite or of the outlines of hornblende.

The groundmass is changed to a fine-grained aggregate of kaolinite, quartz, alunite and pyrite. The last-named mineral occurs also in irregular microscopic veinlets.

As the rock is wholly crystalline and is made up of minerals of approximately constant composition, it is possible to calculate with some precision the actual mineralogical constitution from the chemical analysis. This, in percentages of mass, is as follows : 
Mineralogical Composition of Altered Dacite.

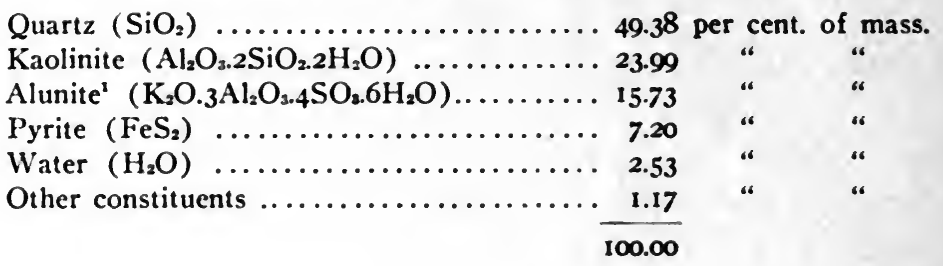

Compared as they stand, the two analyses show close agreement in silica, alumina, titanic oxide and phosphorous pentoxide. When all the iron in both analyses is calculated as ferrous oxide, that of the altered rock shows a loss of only 0.7 per cent., so that in this respect also the two analyses are very close together. On the other hand, the analysis of the altered rock shows a loss of practically all the lime and magnesia, most of the soda and one half of the potash. It has gained a large quantity of combined water, nearly 6 per cent. of sulphuric anhydride and nearly 4 per cent. of sulphur.

Such a direct comparison of analyses, however, while indicating in this case the general character of the change that has taken place in the dacite, is really a comparison of equal masses of the two rocks, or, more strictly speaking, of the two powders as prepared and weighed for analysis, and as Mr. Lindgren ${ }^{2}$ pointed out some years ago, would accurately portray the character of the alteration only under two conditions, namely, (I) that the specific gravity or density of the rock is unchanged by the metamorphism, and (2) that the alteration has not produced any change of volume in the rock mass as a whole, such a change, for example, as takes place when peridotite alters to serpentine. It is essential in an investigation of this kind to determine what materials have been added to or subtracted from a unit volume

\footnotetext{
'The molecular proportions of potash and soda as calculated from analysis II., page 680, are respectively II and 14 All of the potash and 8 of the soda molecules are needed to satisfy the 75 molecules of $\mathrm{SO}_{2}$. Consequently the Goldfield alunite is a soda-bearing variety.

2"Metasomatic Processes in Fissure-veins." Trans. Am. Inst. Mining Eng., vol. 30, 1901, pp. 591-595.
} 
(or unit mass) of fresh rock in order to produce a given alteration product.

The changes undergone by a given volume of rock can be determined most simply if the alteration is unaccompanied by swelling or contraction of the whole rock mass. The altered dacite shows no indication of increase of bulk. The field evidence of such swelling would comprise irregular fracturing and squeezing of the rock, the presence of curved slickensided surfaces, and pressure effects in the microscopical texture of the altered dacite. Contraction would probably be more difficult to detect. Any notable degree of shrinkage, however, would be likely to record itself by the development of many irregular open cracks or by some modification of the original texture of the rock, such as the distortion of phenocrysts. Evidence of either kind being absent, it may be concluded with some confidence that whatever volumetric change has taken place is to be sought in a comparison of the porosity of the two rocks and not in change of total bulk.

The porosity of the fresh dacite is exceedingly slight and is not apparent under the microscope. An accurate specific gravity determination of the rock powder used for analysis, made by $\mathrm{Mr}$. George Steiger, gave the figures 2.654. ${ }^{1}$ He also determined the specific gravity of the whole hand specimen as 2.63 , the difference between the two results being an approximate measure of the porosity. The specific gravity of the altered dacite, which is noticeably porous, as calculated from the mineralogical composition on page 677 , assigning to the I. I 7 per cent. not accounted for the average specific gravity of the other constituents is 2.769. ${ }^{2}$ Determinations by Mr. Steiger gave 2.766 for the powdered rock and 2.49 for the hand specimen. These figures indi-

\footnotetext{
${ }^{1}$ The specific gravities of the powders were determined by placing weighed quantities in water in a tared picnometer and boiling them at low temperature under reduced pressure. They were then kept for some hours in a thermostat and quickly weighed at $25^{\circ} \mathrm{C}$. The specific gravities of the rock masses were obtained by weighing them in air and quickly in water. The figure 2.49 , obtained for the altered dacite, is probably slightly too high in consequence of some absorption by pores open to the surface.

${ }^{2}$ The figures used for the specific gravities of the minerals were: Quartz 2.66, kaolinite $2.6 \mathrm{r}$, alunite 2.60 , and pyrite 5.0.
} 


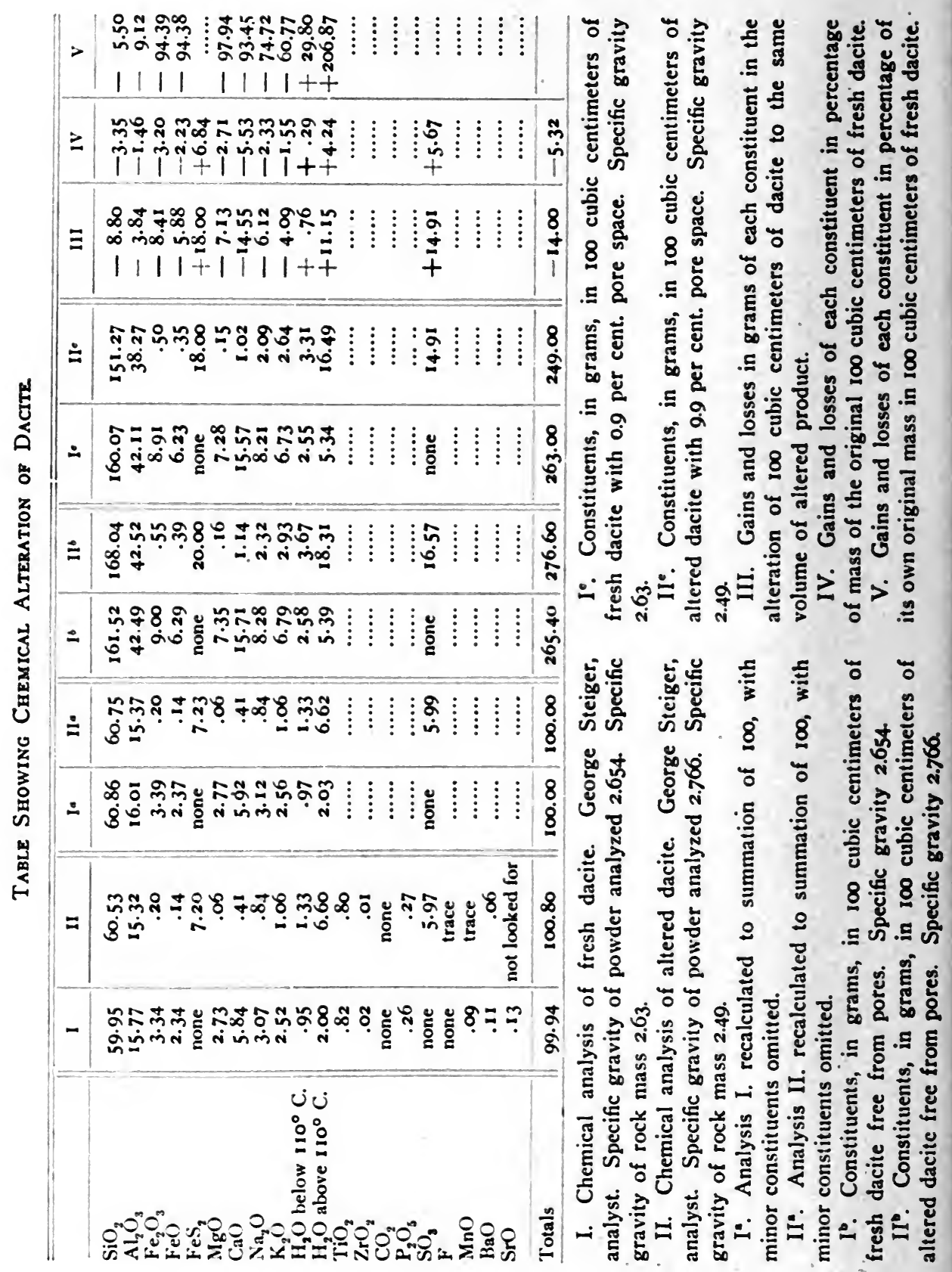


cate that the substance of the altered rock has gained 4.2 per cent. in weight and that, notwithstanding this gain, a given volume of rock, under the supposition of constant volume, has suffered a net loss of 5.3 per cent. in weight consequent upon an increase of porosity.

Since the volume of a given mass of rock, in cubic centimeters, is, for all practical purposes, equal to its weight in grams divided by its specific gravity, the percentage of pore space in the fresh dacite is obtained from the equation

$$
\frac{287.4}{2.63}-\frac{287.4}{2.654}=\frac{287.4}{2.63} x,
$$

where 287.4 is the weight of a specimen of dacite in air, 2.63 the specific gravity of the rock mass, 2.654 the specific gravity of the poreless mineral constituents, and $x$ the proportion of pore space which in this case is equal to 0.9 per cent. In the altered rock, the proportion of pore space is 9.9 per cent., showing an increase in porosity of 9 per cent. of the initial volume.

The chemical changes undergone by the dacite are shown in the accompanying table. Columns $\mathrm{I}^{\mathrm{b}}$. and $\mathrm{II}^{\mathrm{b}}$. are not essential as regards the process illustrated although they represent a step in the reasoning. They are of value also as showing that specific gravity determinations of rock powders, while useful in calculations of the mineral compositions of rocks, are of minor importance in a comparison of this kind, in which it is necessary to know the specific gravity of the mass as a whole, including its pores. Incidentally, it may be remarked that when the specific gravity of a rock is given in connection with its chemical analysis, the method by which the density was determined should be indicated.

In columns $\mathrm{I}^{\mathrm{c}}$. and $\mathrm{II}^{\mathrm{c}}$. are given the number of grams of each constituent in 100 cubic centimeters of each rock, the figures being obtained by multiplying the percentage figures in columns $I^{a}$. and $I I^{a}$. by the respective specific gravities of the fresh and altered dacite. The gains and losses of each constituent are given in grams in column III., and in percentages of total initial 
mass in column IV. The last column, V., gives the percentage of loss of each constituent and perhaps most clearly displays the nature of the change.

It appears that the rock has lost a little of its silica, more of its alumina, nearly all of its magnesia and lime, three fourths of its soda and two thirds of its potash. On the other hand, the water has greatly increased, a large amount of sulphuric anhydride has been added and the iron has been converted to pyrite. The iron oxides in column $\mathrm{I}^{\mathrm{c}}$. correspond to $\mathrm{I} I .08$ grams of metallic iron, while the pyrite in column $\mathrm{II}^{\mathrm{c}}$. corresponds to $\mathbf{8 . 4}$ grams of iron and 9.6 grams of sulphur. The quantity of iron originally in the dacite was therefore not only sufficient to form all the pyrite in the altered rock but has suffered a loss of over 27 per cent.

Comparisons of fresh and altered rocks are sometimes made by assuming the constancy of one constituent and recalculating the analysis of the altered rock accordingly. Such a method, in the present case, would give erroneous results.

The metamorphic agent was evidently a strongly acid solution carrying sulphydric and sulphuric acids, and possibly sulphurous acid. Whether the sulphuric acid which was doubtless the direct agent in the formation of the alunite was present in the original solution from the first, or whether it was derived from the hydrogen sulphide, by oxidation at some stage in the movement of the solution toward its point of attack upon the rocks now visible, is an undecided question. The absence of sulphates from contact ore-deposits indicates, however, that oxygenated sulphur compounds are not given off directly from solidifying magmas. The solution was capable of decomposing the silicates in the rocks, carrying part of their constituents away, reacting with the iron of the magnetite and silicates to form pyrite, with the potassium and aluminium to form alunite and with the aluminium to form kaolinite. The large percentage of loss in calcium, potassium and sodium shows that the active solution was far below its saturation point for these elements and was, therefore, entirely different in character from the supposedly alkaline solutions which deposited the large class of sericitic and calcitic gold- 
quartz veins ${ }^{1}$ exemplified by those of California. Before proceeding farther with genetic considerations I shall briefly describe the mineralogical character of the Goldfield ores.

\section{THE GOLD ORES.}

The typical unoxidized ore as it occurs in the dacite near Goldfield consists of pyrite, bismuthinite and a reddish-gray cupriferous mineral having the general composition of tetrahedrite. Native gold is usually associated with these minerals, particularly with the bismuthinite and tetrahedrite, and in the rich ore may be easily visible. These minerals are often arranged in successive layers or crusts around silicified fragments of dacite, the inner crust being usually the richer.

The brownish copper-bearing mineral, here provisionally called tetrahedrite, contains antimony and sulphur, as chemically determined by Dr. W. T. Schaller, and is therefore not bornite, although it goes by that name in the district. It appears so commonly as a constituent of the best ore that there is a strong suggestion that it is auriferous, particularly as the microscope fails in some specimens of reputed rich ore to reveal any free gold. Further investigation of the mineral is in progress. It may possibly prove to be the orthorhombic species famatinite which contains the same constituents as tetrahedrite, but in different proportions, and is characterized by a reddish tint. Bismuthinite, the sulphide of bismuth, is also regarded by the miners as a sign of rich ore.

Concentric shells of ore minerals about greatly altered rockfragments are rather characteristic of the best ore. Specimens from the Combination mine show an inner zone of free gold and quartz up to an eighth of an inch in thickness. This is covered by a shell of tetrahedrite and this by an outer crust of pyrite. In the Florence mine similar fragments show, first, a shell of pyrite, then one of tetrahedrite, and, finally, a thick crust of quartz speckled with native gold, tetrahedrite and pyrite, and transfixed by needles of bismuthinite. Some of the particles of

${ }^{1}$ See Lindgren, W. “Metasomatic Processes in Fissure Veins." Trans. Am. Inst. Mining Eng., vol. 30, I901, p. 668. 
gold are embedded in the compact quartz, others are inclosed in the bismuthinite. The different crusts are not in every case sharply defined nor are they necessarily continuous.

The native gold of these ores is often in particles so fine and so closely crowded in the gangue that the precious metal resembles a streak of yellow ocher. The proportion of silver is rather small, the average of thirty-four assays of rich ore from the Mohawk mine, made for Mr. J. W. Finch, giving 330 fine ounces of gold and 46.5 ounces of silver to the ton.

Tests and chemical analyses of the ores made for scientific and technical purposes nearly all show a little tellurium, although no tellurium mineral has been recognized in the mines close to Goldfield. Tellurides of gold, not sufficiently well crystallized for a determination of their species, occur in the Jumbo Extension and Goldfield-Belmont mines, near Diamondfield, about four miles northeast of Goldfield, and both tellurite and emmonsite (or durdenite) are found in the oxidized ore of neighboring properties. ${ }^{3}$

A small speck of sphalerite was found by Mr. W. H. Blackburn in the Goldfield-Belmont, but galena has not been noted in any of the mines so far as known. Chalcopyrite, a common mineral in most mining districts, was not found at Goldfield in the course of the present investigation, but it is said to occur sparingly in the Sandstorm and Florence mines.

The common gangue of the unoxidized ore is quartz. This is usually compact, almost flinty, in texture, although porous in mass, and in most cases bears unmistakable evidence of having resulted from the silicification of dacite, rhyolite, or andesite. Large vugs and conspicuously crystalline quartz, such as are found in typical veins the world over, are practically absent from the Goldfield district, where the free development of quartz crystals in open spaces is represented only by drusy films, lining pores left by the solution of phenocrysts or incrusting small interstitial cavities in brecciated material.

Associated with the quartz in much of the ore are soft white substances, such as the miners commonly call "talc." Chemical

'Ransome, F. L. " "Preliminary Account of Goldfield, etc." Bull. U. S. Geol. Survey No. 303, 1907, p. 36. 
and microscopical tests of the white material show that in most cases it is either alunite or kaolinite or a mixture of the two. ${ }^{1}$ Sericite, supposed when the preliminary report ${ }^{2}$ on the district was written to be also abundant, proves on further study to be very rare and is certainly nowhere an abundant or characteristic mineral in the ore deposits. Gypsum, while not known with actual sulphide ore, is very abundant in the altered rocks within a hundred feet or so from the surface and does occur crystallized with quartz and pyrite on the Goldfield-Belmont mine, below the belt of oxidation.

As a rule, the gold and auriferous sulphides are embedded in quartz. Alunite, however, is often so close to the gold as to appear in the same microscopic field and the telluride of gold in the Jumbo Extension mine is partly embedded in alunite.

The ores, it should be noted, do not occur in typical veins but in masses of shattered, altered rock of very irregular shape. In small part only do they appear to have filled visibly open cavities or fissures.

For descriptions of the oxidized ores, which have been of so much importance at Goldfield, the reader is referred to the advance report cited and to the forthcoming memoir on the district. In some places they contain alum derived from the alunite.

\section{THE ORE-DEPOSITING SOLUTIONS.}

The mineralogical character of the Goldfield ores and the alteration of the wall rock show that the solutions or vapors which deposited them carried gold, copper, bismuth, antimony, a little arsenic and tellurium, hydrogen sulphide, and probably sulphurous and sulphuric acids. The solvent action of the solutions upon quartz was comparatively slight, as shown by the fact that the original phenocrysts of the dacite still retain their characteristic embayed outlines when the rest of the rock is altered

${ }^{2} \mathrm{Mr}$. E. A. Collins, in his recent good description of the Combination mine (Mining and Scientific Press, vol. 95, 1907, p. 398) refers to the ore as " a mixture of soft kaolinized material and hard dacite." The "kaolinized material" is chiefly alunite.

${ }^{2}$ Bull. U. S. Geol. Survey No. 303, 1907, p. 35. 
to quartz, alunite and kaolinite. The quartz set free by the decomposition of the silicates has for the most part recrystallized as fine-grained aggregates. A small proportion, as we have seen, has been carried away in solution, perhaps in part to be recrystallized in small neighboring fissures, and in part permeating the surrounding less altered rocks. Large masses of coarsely crystalline vein quartz are absent from this district and it seems necessary to conclude, that the ore-bearing solutions were not only poor in silica but that, in spite of their energetic attack upon the rocks, they were not good solvents for quartz. The apparently intense silicification of the country rock in proximity to fissures appears at first glance to point to a different conclusion. The conversion of a rock containing 60 per cent. of silica to a finegrained, pyritic, quartz aggregate does not, however, necessarily imply the direct addition of 40 per cent. of silica. The result may be attained by the removal of most of the bases, the conversion of the iron to pyrite and the development of a porous texture such as is favorable for ore deposition and is characteristic of the Goldfield ledges. Moreover, it is probable that some of the silica shown to have been abstracted from the altered dacite may have been concentrated in the immediate vicinity of the fissures. Certainly, whatever silica was originally in the solutions did not travel far from the fissures through which they rose.

Whether the solutions were notably ferruginous is doubtful. As compared with other districts, the pyrite at Goldfield is not abundant and all of that in the country rock can, as has been shown, be accounted for without any addition of iron. There has, in fact, been an abstraction of iron which may have been sufficient to form the pyrite in the actual ore, upon the supposition that the dissolved iron, like the silica, migrated toward the fissures.

In general the heavy metals brought in by the solutions remained within or very close to the multitude of small, irregular fissures that afforded opportunity for the depositional process. The sulphur acids, on the other hand, penetrated the wall-rock for considerable distances. 
It is very probable that the ore-bearing solutions contained carbon dioxide, although the ores and the rock adjacent to them are free from carbonates. Field evidence in this district, as well as in the Cœur d'Alene district ${ }^{1}$ in Idaho, indicates that this constituent, when of volcanic origin, becomes active in the formation of carbonates only at comparatively low temperature and that it tends to penetrate to greater distances from the source of supply than some of the other constituents. The third, or propylitic type of alteration described on page $67 \mathrm{I}$, is thought to be largely due to the extensive permeation of the rocks by solutions containing carbon dioxide. It thus constitutes an outer aureole to the more intense metasomatism associated directly with the ores. I hope at a future time to study in detail the relation of the metamorphism particularly described in this paper to that of this outer zone.

It may be recalled, in this connection, that Sainte-Claire Deville and Leblanc, 2 in their studies of Italian volcanic gases, found that sulphurous and carbonic acids never occurred together, although the association of sulphydric and carbonic acids was frequent. They concluded that, as a rule, the emanation of carbon dioxide marks a later and cooler stage of solfataric activity. The transition from one type to the other, however, can hardly be abrupt.

Just what became of the lime and magnesia removed from the altered dacite has not been determined. A part, at least, of the calcium was probably taken into solution as hydrous sulphate and deposited in fissures as gypsum, this mineral being known to occur in the district in places where its formation can scarcely have resulted from the action of surface waters. Still another part and some of the magnesium may have been carried as carbonates into the rocks affected by metamorphism of the third or propylitic type and there deposited metasomatically as calcite or dolomite. It has not yet been ascertained, however, whether

\footnotetext{
${ }^{1}$ Ransome and Calkins. "The Geology and Ore Deposits of the Cœur d'Alene District." Profess. Paper U. S. Geol. Survey. In press.

2 "Mémoire sur la composition chimique des gaz rejetés par les évents volcaniques de l'Italie méridionale." Ann. de Chimie et de Phys., vol. 52, 1858 , p. 45 .
} 
there has actually been any addition of calcium or magnesium to these carbonatized rocks.

Two general hypotheses are entertainable with reference to the source of these solutions. They either came from above, the sulphurous or sulphuric acid having been derived from overlying deposits of oxidizing sulphides, or they came from below. In the former case the solutions were presumably cold; in the latter case they were in all probability hot. The difficulties in the way of the descensional hypothesis, however, appear to be insurmountable.

All available geological evidence indicates that the ore deposits of Goldfield were formed comparatively near the surface and that consequently they do not represent the final stage of a long period of erosion and progressive downward enrichment. The irregularity and sporadic occurrence of the ore bodies would seem to be alone sufficient to render any such long-continued enrichment impossible. We are driven then to suppose that if descending solutions effected the intense metasomatic action described, these must have derived their chemical energy from the oxidation of moderate quantities of pyrite comparatively near at hand. Under such circumstances, the effect produced appears to be greatly disproportioned to the available agency. Such a process might account for the development of kaolin and perhaps some alunite within the oxidized ore, but hardly for the extensive metasomatism of the country rock which is not limited to the vicinity of known ore bodies and continues far below all traces of oxidation as measured by the presence of iron oxides. For it is to be borne in mind that the alteration described in this paper is characteristically associated with unoxidized ores and that gold, pyrite, tetrahedrite, bismuthinite and the other minerals found in such ores were deposited at the same time that the neighboring rock was changed to quartz, alunite and kaolinite. If the alunitization is the work of cold descending solutions then the rich ores of Goldfield are entirely the product of the same agency. In the light of our present knowledge of ore deposition, this seems improbable. 
The intensity of the alteration and the character of the solutions, as shown by the composition of the ores and by the metasomatism of the country rock, point to hot ascending waters as the effective agent. Even the alunite, in spite of the occurrence of the mineral in the oxidized ore of some of the Cripple Creek mines and the view held by De Launay with regard to the Tolfa occurrence, is suggestive of more intense chemical activity than is usually manifested by cold oxidizing solutions. The Goldfield region, moreover, is known to have been the scene of volcanic activity throughout most of Tertiary time. That the solutions were essentially emanations from a solidifying body of dacitic magma - the reservoir whence came the intrusive dacite and the extrusive dacite vitrophyre of the district, is regarded as a probable hypothesis. It is significant in this connection that a chemical analysis of the glassy, effusive dacite vitrophyre shows 3.35 per cent. of water driven off below $110^{\circ} \mathrm{C}$. and 4.06 per cent. lost above that temperature, a total of 7.4I per cent. The intrusive dacite on the other hand contains 2.95 per cent. of water, 2 per cent. being driven off above $110^{\circ} \mathrm{C}$. The dacitic magma thus originally contained a large quantity of water and that much of this water has been expelled during crystallization is shown by the difference of over 4 per cent. between the water of the two analyses.

The limits of a brief paper do not permit of a full discussion of the question of the thickness of the overlying rocks at the time the ores were deposited. General geological evidence which will be set forth in a later publication indicates that the ores were deposited at comparatively shallow depth.

\section{ORIGIN OF KAOLINITE.}

Some discussion has been waged in the literature of ore deposits regarding the origin of kaolin and Mr. Lindgren ${ }^{1}$ has recently intimated that, although he himself formerly referred to it as characteristic of certain classes of veins, kaolinite should

s "The Relation of Ore-deposition to Physical Conditions." This journal, vol. II., I907, p. I20. 
not be considered as a gangue mineral of any class of ore deposits except those formed under the influence of oxidation. In a subsequent paragraph he somewhat modifies this statement by the expression of belief that "kaolin is rarely formed by alkaline hot water at any considerable depth below the surface."

Much kaolin originally described by various authors as formed by the solutions which first brought up the ores associated with it, has later been proved to have resulted from oxidizing processes, it being one of the most characteristic products of the action of percolating acid solutions upon aluminous rocks. The kaolin at Cripple Creek is a good example. Much so-called kaolin, moreover, has been shown to be sericite, and some is perhaps alunite. These facts, however, seem scarcely to warrant the total elimination of kaolinite from the list of gangue minerals found in unoxidized ore deposits. The mineral undoubtedly occurs as an original constituent of some of the ores of the San Juan Mountains, Colorado. ${ }^{1}$ Mr. W. H. Weed ${ }^{2}$ has described it as a product of the metasomatic action of the waters of Boulder Hot Springs, Montana, upon granite, and according to Mr. S. F. Emmons ${ }^{3}$ the mineral is an abundant original constituent of the ore of the Bassick mine. Kaolinization has also been noted by Béla von Inkey ${ }^{4}$ in the dacitic country rock of the Nagyág veins, the material being afterwards investigated by F. Kollbeck, ${ }^{5}$ whose analysis indicates a mixture of kaolinite and sericite.

At Goldfield, the intimate association of the kaolinite with the alunite, gold and sulphides shows that all were formed at the same time and by one general process which was anterior to and entirely independent of oxidation or weathering. These latter

'Ransome, F. L. " Economic geology of the Silverton Quadrangle, Colo." Bull. U. S. Geol. Survey No. 182, 1901, p. 73.

" "Mineral Vein Formation at Boulder Hot Springs, Montana." 2ist Ann. Report U. S. Geol. Survey, 1900, part 2, p. 253.

" Geology of Silver Cliff and the Rosita Hills, Colorado." By Whitman Cross. Accompanied by a paper on the mines of Custer County, Colorado. By S. F. Emmons, I7th Ann. Rept. U. S. Geol. Survey, I896, part 2, p. 432.

-“Nagyág und seine Erzlagerstätten." Budapest, I885, p. 143.

s"Untersuchungen über die Zersetzung des Quarztrachyts neben Golderzgängen von Nagyág." Oesterr. Zeits. f. Berg- und Hüttenciesen, vol. 36, 1888, pp. 25-27. 
processes have probably also resulted in the formation of some kaolin, but with this secondary development the present paper is not concerned beyond the pointing out of the distinction between the two modes of genesis.

\section{CONCLUSION.}

The recognition of alunite as a characteristic constituent of the Goldfield ores and the demonstration of its genetic relation to them establishes a new type-that of alunitic and kaolinitic goldquartz veins, in the classification of epigenetic deposits based upon the kind of metasomatism effected in the wall-rock by the ore-depositing solutions. While the Goldfield deposits are probably too irregular in form to come under the usual definition of vein, yet in all that relates to genesis of the ores there is no essential difference between them and what is usually termed a metasomatic fissure-vein.

It is not believed that the Goldfield district is unique in the possession of this type. Other examples are likely to be found among the great number of ore deposits associated with Tertiary volcanism, particularly when more investigators of mining districts realize the importance of close studies of rock alteration, such as have been so admirably carried out in this country by Mr. Lindgren and in Europe by the late Professor Stelzner, and when they accept neither kaolinite nor sericite on faith and external appearance.

In spite of the mass of evidence which indicates the deposition of a large class of gold veins by highly siliceous alkaline solutions, it is clear that some deposits, and those of remarkable richness, may be formed by acid solutions. To explain this essential difference in the vein solutions is one of the most absorbing problems connected with ore genesis. It is possible that emanations from a crystallizing magma may be normally and initially acid but become modified by passage upward through the rocks. If there is any truth in this suggestion, then ores such as those of Goldfield are deposited comparatively near to the source of the solutions. Of course, the extent to which 
initially acid emanations would be neutralized and modified in their ascent through fissured rock would depend not only upon distance but very largely upon the kind of rock traversed, the quantity and character of admixed surface-derived waters, and the pressure and temperature gradients.

It may also be pointed out that the constituents removed from the Goldfield rocks are those which are deposited extensively in the production of gold-quartz veins of the sericitic and calcitic type. Consequently, conditions are easily conceivable under which the acid solutions of Goldfield might have ascended through a much thicker series of rocks and given rise to sericitic and calcitic veins.

Finally, the relation of the alunite and kaolinite at Goldfield suggests the attractive possibility of the future discovery of metasomatic veins of the pure alunitic type, without kaolinite.

While the available facts in the Goldfield district appear to justify the conclusions drawn in this paper, the cautious reader may well share with the writer a certain reserve in judgment, in view of the moderate depth, about 300 feet, to which study of these deposits has necessarily been limited. The possibility that more than one process has contributed to the concentration of the sulphide ores and to the alteration of the rocks is one that cannot be entirely eliminated until the mines have been opened to greater depths. 





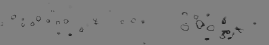

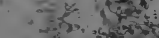

$x^{2}$
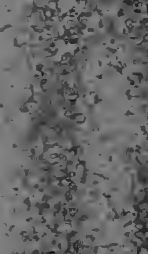

$\rightarrow y$
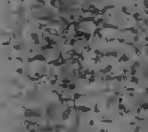

Tes: $\because 7$

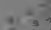

$=1,1$

$122 \div$

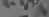

$=-b_{1}, 1$

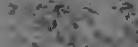

$378 \div$

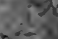

$-\frac{1}{2}$

$1+10$

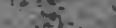

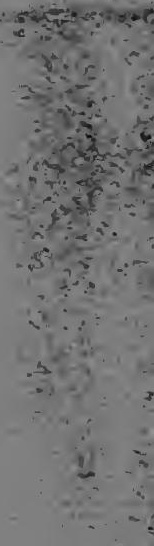

8

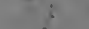

$\therefore$

to. 


$y_{1}$

边,

atis

mint.

3
3 W

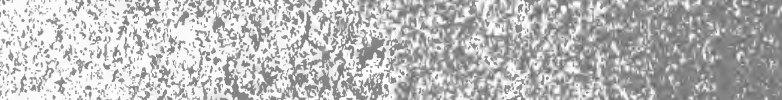
W.t. 16.7. W.

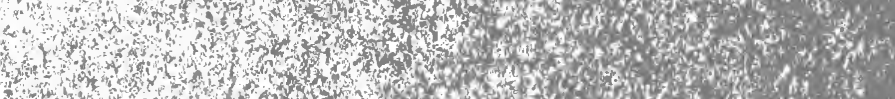
2.t. w. H.t. 17,

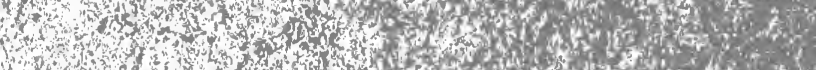
H.7.7. 17.6. W. H.t. W 4.

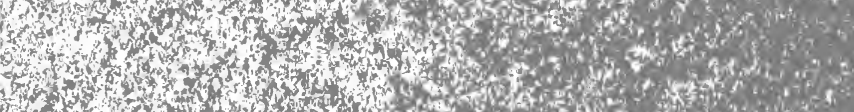

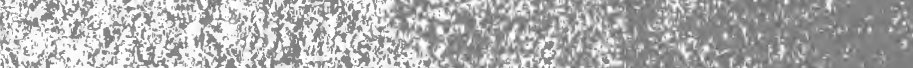

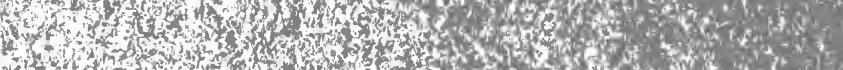
3.t.

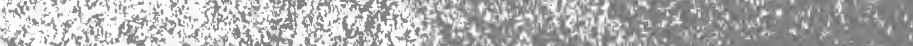

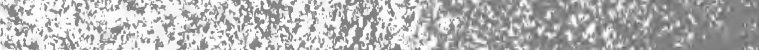

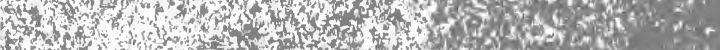

H

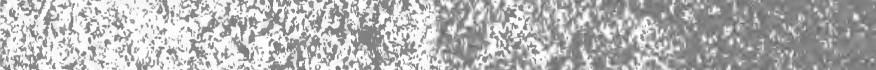
W

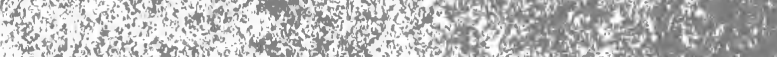
1,

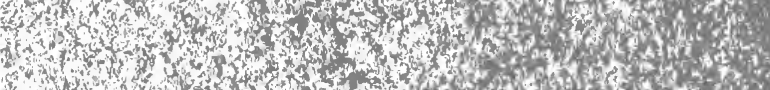

W W W W W

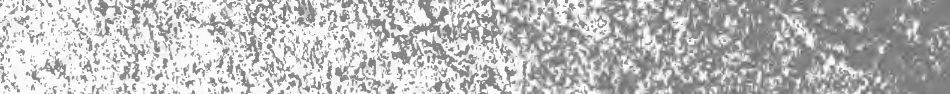

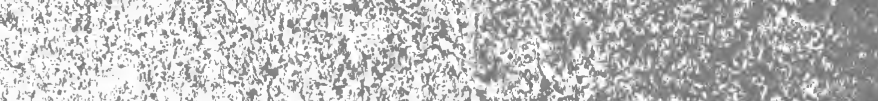

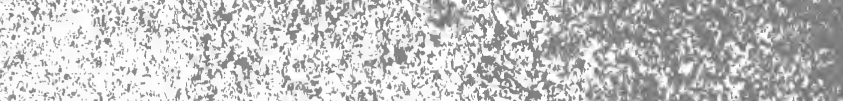

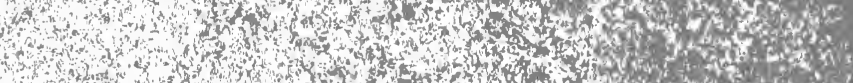
a.

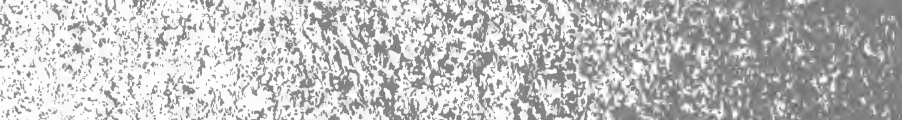

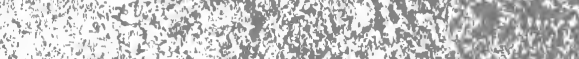

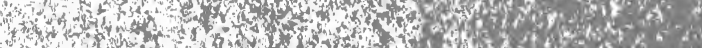

